\title{
Big sacaton and endophyte-infected Arizona fescue germination under water stress
}

\author{
KAESHA L. NEIL, RONALD L. TILLER, AND STANLEY H. FAETH
}

First author is Undergraduate Student and third author is Professor of biology, School of Life Sciences, Arizona State University, Tempe, Ariz., 85287. At the time of the research, the second author was Graduate Research Assistant, Plant Biology Department, Arizona State University, Tempe, Ariz., 85287.

\begin{abstract}
Water availability in the germination stage of plants is crucial for seed germination and as a resource for developing seedlings. The effect of osmotic potential on percent germination and time to germination for big sacaton (Sporobolus wrightii Munro) and Arizona fescue (Festuca arizonica Vasey) was investigated. We predicted that seeds native to semi-arid environments would germinate at osmotic potentials less negative than about -1.5 MPa, the permanent wilting point (PWP) of many agronomic grasses. In addition, the systemic, asexual endophyte Neotyphodium is transmitted through the seed in Arizona fescue and is thought to increase germination of its host. Therefore, we also tested for an effect of the endophyte on germination and time to germination of Arizona fescue under varying osmotic potentials. To test for minimum osmotic potential supporting germination, big sacaton and Arizona fescue seeds were placed on acetate membranes in contact with PEG solutions of varying osmotic potentials for 2 weeks. Both grasses germinated at $50 \%$ of maximum germination (at soil saturation) at and below the standard PWP (-1.5 Mpa). Big sacaton and Arizona fescue germinated at $64 \%$ and 60\% at -1.5 MPa, respectively, and Arizona fescue germinated at $35 \%$ at $-1.8 \mathrm{MPa}(70 \%$ was the maximum at saturation). The presence of the Neotyphodium endophyte did not affect percent or time to germination of Arizona fescue at any of the osmotic potentials tested.
\end{abstract}

Key Words: Festuca arizonica, Neotyphodium endophytes, osmotic potential, permanent wilting point, semi-arid habitats, Sporobolus wrightii

Establishment and survival of plants in semi-arid regions depends initially on successful germination of seeds under low and ephemeral water conditions. Low osmotic potentials often delay radicle emergence and decrease germination (McGinnies 1960, Qi and Redmann 1993, Brown 1995). Studies that have examined success and timing of germination of semi-arid, native grass species under varying osmotic potentials report that these species have similar osmotic potential requirements as agronomic

Research was funded in part by a grant from the Howard Hughes Medical Institute through the Undergraduate Biology Enrichment Program, National Science Foundation grants DEB 9727120 and 0128363, and the State of Arizona Game and Fish Department 11PAM Heritage Fund. Authors thank Dr. J. Stutz for providing workspace and the people in S.H.F.'s lab for their help and encouragement.

Manuscript accepted 27 Jan. 03.

\section{Resumen}

La disponibilidad de agua durante la etapa de germinación es crucial para que las semillas germinen y como recurso para el desarrollo de las plántulas. Se investigó el efecto del potencial osmótico en el porcentaje y tiempo de germinación del "Big sacaton" (Sporobolus wrightii Munro) y "Arizona fescue" (Festuca arizonica Vasey). Predijimos que las semillas de los ambientes semiáridos germinarían a potenciales osmóticos menos negativos de aproximadamente -1.5 Mpa del punto de marchitez permanente (PMP) de la mayoría de pastos utilizados agronómicamente. Además, en el "Arizona fescue" el hongo endófito, sistémico y asexual, Neotyphodium se transmite a través de la semilla y se piensa que incrementa la germinación de su hospedero. Por lo tanto, también probamos el efecto del hongo endófito en la germinación y el tiempo de germinación del "Arizona fescue" bajo varios potenciales osmóticos. Para evaluar el potencial osmótico mínimo que sostiene la germinación, el "Big sacaton" y el "Arizona fescue" se colocaron por dos semanas en membranas de acetato en contacto con soluciones de PEG de varios potenciales osmóticos. Ambos zacates germinaron al 50\% de la germinación máxima (en suelo saturado) en y abajo del PMP estándar (-1.5 Mpa). A -1.5 MPa el "Big sacaton" y el "Arizona fescue" tuvieron un porcentaje de germinación de $64 \%$ y $60 \%$ respectivamente, y el "Arizona fescue" germinó un 35\% a $-1.8 \mathrm{MPa}(70 \%$ de la saturación máxima). La presencia del hongo endófito Neotyphodium no afectó ni el tiempo ni el porcentaje de geminación del "Arizona fescue" en ninguno de los potenciales osmóticos evaluados.

grass species (Briedé and McKell 1992, Hardegree and Emmerich 1992, Qi and Redmann 1993, Adams 1997). One study, however, found that Idaho fescue (Festuca idahohensis Elmer) germinated over a wider range of osmotic potentials with higher germination percentages than non-semi-arid species (Brown 1995), suggesting that native, semi-arid grasses may have adapted to germinate at lower osmotic potentials.

In addition, many pooid grasses are infected with systemic, seed-borne endophytes such as Neotyphodium (e.g., Clay 1990). Neotyphodium is an asexual fungus that inhabits above-ground tissues of grasses, remains asymptomatic, and often produces alkaloids (Saikkonen et al. 1998, Schulthess and Faeth 1998). These endophytes are vertically-transmitted by hyphae growing into developing seeds (Saikkonen et al. 1998). Systemic endophytes may benefit host grasses in several ways, such as by increasing drought tolerance, herbivore resistance, and seed ger- 
mination (Clay 1987, Latch 1993, Elmi and West 1995, Schulthess and Faeth 1998). Arizona fescue (Festuca arizonica Vasey) plants are usually infected (60 to $100 \%$ of individuals within a population) with the endophyte Neotyphodium starrii (MorganJones and Gams) (Schulthess and Faeth 1998), but generally show no increased resistance to herbivores or increased drought resistance at the adult stage (Faeth 2002, Faeth and Bultman 2002, Faeth and Sullivan 2003). Thus, the possible increased germination success of infected seeds may explain the persistence of high levels of infection in natural populations.

We determined the effect of varying osmotic potentials on percentage germination and time to germination of big sacaton (Sporobolus wrightii Munro) and Arizona fescue seeds, 2 native grasses, in germination vials with varying osmotic potentials. These grasses were used in this study because they are native, historically and economically important southwestern US forage grasses, and non-commercial seeds of these species were readily available. We also tested whether the endophyte Neotyphodium starrii alters percentage germination of Arizona fescue. We predicted that infected $(E+)$ seeds should have higher percent germination than uninfected (E-) seeds.

\section{Methods And Materials}

\section{Big Sacaton}

Big sacaton is a warm-season $\left(\mathrm{C}_{4}\right)$, perennial bunchgrass that grows in dense clumps. It is grazed by cattle and horses in early spring and, has been used historically for making hay (Humphrey 1970). It is found in dry, open, and sandy plains, bottomlands, riverbanks, and alluvial flats from 600 - to 1,980 -meters elevation. Big sacaton extends from western Texas to California and into central Mexico (Kearney and Peebles 1960, Humphrey 1970, USDA Forest Service 1988). It is drought-resistant, but only after becoming established. Occasional flooding appears necessary for seedling growth (USDA Forest Service 1988). Seeds for this experiment were collected from many individuals in an alluvial bottomland at Gardner Creek, $63 \mathrm{~km}$ southeast of Tucson, Ariz., U.S.A. (N $\left.31^{\circ} 45^{\prime} \mathrm{W}^{\circ} 110^{\circ} 36^{\prime}\right)$, in the fall of 1998.

\section{Arizona Fescue}

Arizona fescue is a cool-season $\left(\mathrm{C}_{3}\right)$, dense, perennial, montane bunchgrass and is important late-season forage for cattle, horses, and sheep (USDA Forest Service 1988). It is native throughout the southwestern United States in open, semi-arid Ponderosa pine forests and dry plains from 1,830 to $3,050 \mathrm{~m}$ elevation (Kearney and Peebles 1960, USDA Forest Service 1988). Seeds for this experiment were collected in the summer of 1999 from clones of 4 infected (hereafter, E+) maternal plants in an experiment in progress at the Arboretum of Flagstaff, Ariz., U.S.A (N $\left.35^{\circ} 10^{\prime} \mathrm{W} 111^{\circ} 43^{\prime}\right)$. All maternal plants originated from Merritt Draw, about 10 $\mathrm{km}$ east of Clint's Well, Ariz. (N 34 ${ }^{\circ} 29^{\prime}$ $\left.\mathrm{W} 111^{\circ} 11^{\prime}\right)$. The endophyte was removed from some clones of each maternal plant using the procedure described in Faeth and Fagan (2002) and Faeth and Sullivan (2003). These clones produced uninfected (hereafter, E-) seeds after 2 seasons of growth in the field.

\section{Design of Germination Vials}

Seeds were germinated in vials modeled after Hardegree and Emmerich (1992, Fig. 1). Germination vials were constructed with the following components: a 50-mm diameter by $110-\mathrm{mm}$ high transparent, snap-top plastic vial (Thornton Plastics, Utah, USA); a platform made of extruded acrylic plastic rods $(50 \mathrm{~mm}$ tall) glued (Ambroid ProWeld ${ }^{\circledR}$, N.H., USA and Plastruct PlasticWeld ${ }^{\circledR}$, Calif., USA) to the inside of the vial; and a smaller, transparent plastic, snap-top vial with a diameter of $30 \mathrm{~mm}$. The bottom of the smaller vial was removed to make the vial $26 \mathrm{~mm}$ deep and a $23 \mathrm{~mm}$ diameter hole was cut into the lid. A cellulose acetate membrane (molecular exclusion weight 3,500 ), which prevents the transmission of PEG, was placed over the vial's opening and the lid was snapped on over it. The smaller vial (hereafter germination cup) was inverted and placed on the stand inside the larger vial.

\section{Preparation of the Appartus and PEG Solutions}

Acetate membranes were soaked in distilled water for about 10 minutes and rinsed 3 times with distilled water. The membranes were snapped onto the germination cups with the lids, and excess water was removed before placement in the larger vials. To equilibrate the membranes with the osmotic solution of polyethylene glycol 8000 (PEG, Baker), about $90 \mathrm{ml}$ of solution was poured into each vial with the germination cups (membrane in contact with the solution) 2 days before the seeds were placed in the germination cups. Therefore, when seeds were placed on the acetate membrane, they were in contact with the osmotic solution. The larger vial's lid was snapped in place to make a closed system (Fig. 1).

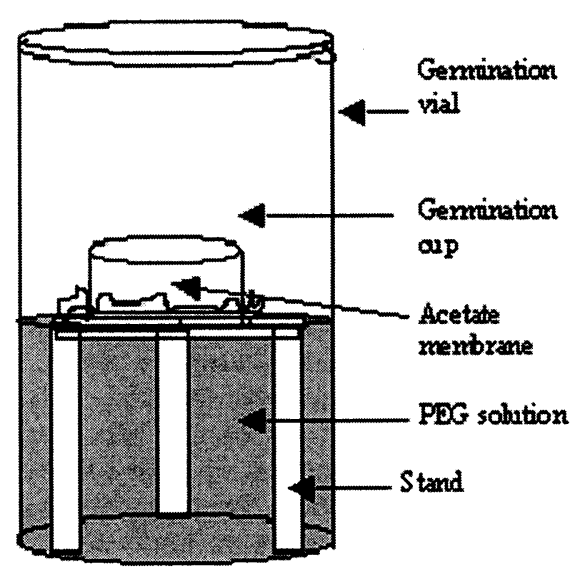

Fig. 1. Schematic of germination vial with germination cup (not drawn to scale). See text for a description of the apparatus.

To confirm the actual osmotic potentials, the various experimental PEG solutions were tested for actual osmotic pressure using a Wescor Vapor Pressure Osmometer at the respective temperatures. Standard curves were derived using 5 KCL standards. Each experimental PEG solution was tested in triplicate. The observed mean $\mathrm{MPa}$ of each solution at each temperature was within 0.10 standard deviation (or 0.06 standard error) of the expected, indicating a close agreement of actual MPa of PEG solutions to expected $\mathrm{MPa}$.

\section{Germination Tests}

To test the effect of osmotic potential and the endophytic fungus, germination vials with big sacaton seeds were placed randomly in a complete block design and set in a growth chamber. Vials with Arizona fescue seeds were placed randomly in a complete block design on a lab bench. The growth chamber with the sacaton seeds was set to 12 hours of light at $34^{\circ} \mathrm{C}$ and 12 hours dark at $18^{\circ} \mathrm{C}$. The room in which the Arizona fescue seeds were placed was maintained at temperatures between 23 and $26^{\circ} \mathrm{C}$

There were 6 big sacaton treatments with 6 replicates of 50 seeds each. There were 12 Arizona fescue treatments with 6 replicates of 25 seeds each. Although there were only 6 different osmotic solutions used with the Arizona fescue seeds, each infection type (E- or $\mathrm{E}+$ ) and osmotic solution combination was used. Osmotic 
solutions were made by mixing PEG with distilled water. The following solutions were made for the big sacaton seeds: 0 , $-0.3,-0.9,-1.5,-2.25$, and $-3.0 \mathrm{MPa}$. The following solutions were made for the Arizona fescue seeds: $0,-0.6,-0.9,-1.2$, -1.5 , and $-1.8 \mathrm{MPa}$. The PEG/water ratios were calculated based on the following formula by Michel (1983):

$$
\psi=1.30[\mathrm{PEG}]^{2} T-137[\mathrm{PEG}]^{2}
$$

where $\psi$ is osmotic potential and $T$ is temperature. Big sacaton seeds were checked for germination on days $1,2,3,4,6,8,10$, and 15. Observation occurred on days 1,2 , $3,6,8,10,12$, and 14 for the Arizona fescue seeds. Removal of the lids when checking for germination also allowed fresh air into the vials. Seeds were considered germinated and were removed from the vials when a distinct radicle had emerged.

Repeated measures ANOVA (Systat 10.0 GLM procedures) was used to test for differences in percent germination among treatments (between-subjects factor), with time (day of germination) as a within-subjects factor for big sacaton. Similar tests were also used for the Arizona fescue treatments and to test for differences in mean percent germination among treatments and by infection status (betweensubject factors) over time (within-subject factor). Difference in cumulative percent germination across all time periods was tested with variation among replicates within osmotic treatments. Percent germination was arcsine transformed (Sokal and Rohlf 1995) for all analyses. Post hoc tests (Tukey HSD, Sokal and Rohlf 1995) were used for pair-wise comparisons among treatments for both plant types and for pair-wise comparisons of percent germination among treatments and infection status over time for Arizona fescue. Repeated measures univariate $F$ tests were also used to compare differences in percent germination between adjacent sampling periods. All assumptions of ANOVA were tested and met.

\section{Results}

\section{Big Sacaton}

Big sacaton cumulative germination exceeded $50 \%$ at osmotic potentials as low as $-1.5 \mathrm{MPa}$ (Fig. 2). The greatest germination $(98.7 \%)$ occurred at $0.0 \mathrm{MPa}$, declined to $64.2 \%$ at $-1.5 \mathrm{MPa}$, and then declined steeply to $8.3 \%$ at $-2.25 \mathrm{MPa}$ (Fig. 2). Overall, percent cumulative germination showed a treatment effect (Table 1). Pairwise comparisons (Tukey HSD

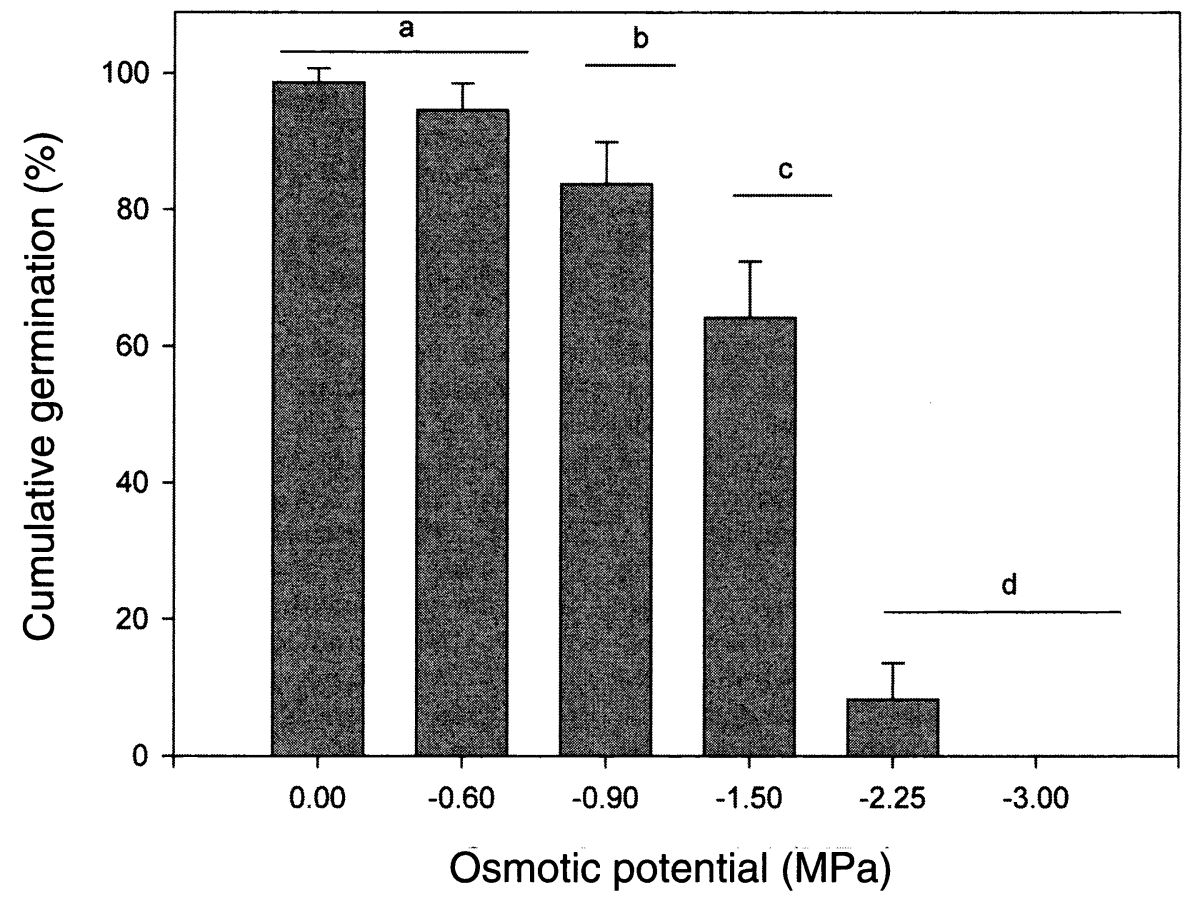

Fig. 2. Mean $( \pm S E)$ cumulative percent germination of big sacaton at different osmotic potentials. Different letters above bars indicate mean significant differences $(P<0.05$, Tukey HSD test). tests) of treatments indicated cumulative germination in all treatments differed from each other $(\mathrm{P}<0.01)$, except mean germination in treatments $0.0 \mathrm{MPa}$ and -0.60 $\mathrm{MPa}$ and treatments $-2.25 \mathrm{MPa}$ and -3.00 $\mathrm{MPa}(\mathrm{P}>0.05)$ (Table 1).

Percent germination also showed a time effect (Fig. 3, Table 1). Germination among various osmotic potentials also varied differently over time (Fig.. 3, Table 1, time $x$ treatment effect). Generally, seeds in the less negative osmotic potentials germinated earlier than those in more negative osmotic potential treatments (Fig. 3). Germination in the $0.0 \mathrm{MPa}$ and $-0.6 \mathrm{MPa}$ treatments peaked on day 2 , in the -0.9 $\mathrm{MPa}$ treatment on day 3 , and in the -1.5 $\mathrm{MPa}$ and $-2.25 \mathrm{MPa}$ treatments on day 6 and 8, respectively (Fig. 3). No germination occurred in the $-3.0 \mathrm{MPa}$ treatment (Fig. 3). Percent germination differed among all adjacent time periods (univari- ate $\mathrm{F}$ tests, $\mathrm{P}<0.01)$, except between days 10 and $15(\mathrm{P}=0.37)$

\section{Arizona Fescue}

Cumulative percent germination of Arizona fescue differed among the osmotic potential treatments (Figure 4, Table 2, treatment effect). However, cumulative percent germination remained high (> $60 \%$ ) as osmotic potentials became more negative and did not decline significantly until $-1.5 \mathrm{MPa}$ (Tukey HSD test, $\mathrm{P}=$ 0.031). An additional decrease in osmotic potential further reduced cumulative percent germination (Fig. 4, $\mathrm{P}<0.001$ ). Germination at all osmotic potential treatments varied with time (Table 2, time effect). Univariate $F$ tests indicated that germination differed among treatments in all adjacent time periods. At more negative osmotic potentials, there was a trend
Table 1. Repeated measure analysis of variance of the effect of osmotic potential (OP) treatments on percent and timing (day) of germination of big sacaton.

\begin{tabular}{ccrccc}
\hline \hline Source & Sum of Squares & df & Mean Square & F-ratio & $P$ \\
\hline Between Subjects & 1690.4 & 5 & 338.1 & 463.2 & 0.000 \\
OP & 21.9 & 30 & 0.7 & & \\
Error & & & & & \\
Within Subjects & 2875.8 & 7 & 410.8 & 69.4 & 0.000 \\
Day & 9726.2 & 35 & 277.9 & 47.0 & 0.000 \\
Day x OP & 1242.6 & 210 & 5.9 & & \\
Error & & & &
\end{tabular}




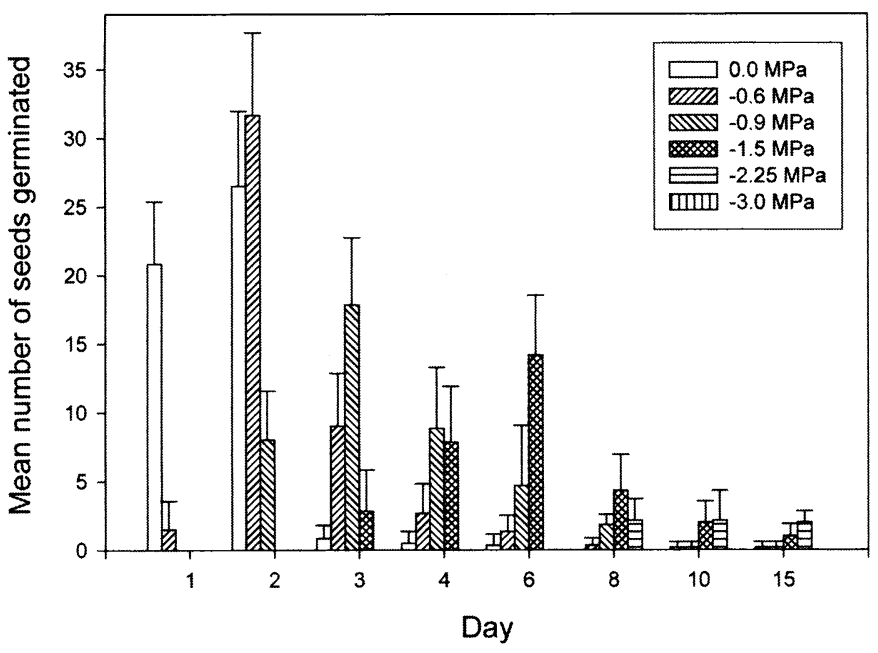

Fig. 3. Mean $( \pm$ SE) germination success of big sacaton over a 15-day period at different osmotic potentials. Each bar represents the mean $( \pm$ SE) of 6 replicates of experimental units of 50 seeds.

for delay of germination of Arizona fescue. Germination peaked on day 3 and 6 for the $0.0 \mathrm{MPa}$ treatment, on day 6 for treatments $-0.3 \mathrm{MPa}$ and $-0.9 \mathrm{MPa}$, on day 8 for treatments $-1.2 \mathrm{MPa}$ and -1.5 $\mathrm{MPa}$, and on day 12 for treatment -1.8 $\mathrm{MPa}$ (Fig. 5).

The presence of the endophyte did not affect cumulative percent germination (Fig. 4, Table 2, no endophyte effect) nor did cumulative percent germination of $\mathrm{E}+$ and E- seeds interact differently with changing osmotic potentials (Table 2, no endophyte $x$ treatment interaction). Furthermore, germination of E+ and Eseeds did not differ among treatments over any of the time periods (Fig. 5, univariate F tests, $\mathrm{P}>0.24)$.

\section{Discussion and Conclusion}

\section{Big Sacaton}

Relative germination of big sacaton seeds was greater at more negative $\mathrm{MPa}$ values than many other warm-season, semi-arid native grasses. For example, Baskin and Baskin (1998a) reported that weeping lovegrass (Eragrostis curvula Schrad.), Lehmann lovegrass (E. lehmanniana), tobosa grass (Hilaria mutica Buckl.), Johnson grass (Sorghum halepense L.), alkali sacaton (Sporobolus airoides Torr.), spike dropseed (S. contractus), and sand dropseed (S. cryptandrus Torr.) declined to less than $50 \%$ germination at osmotic potentials more negative than $-1.5 \mathrm{MPa}$. Instead, big sacaton appears to germinate similar to sideoats grama (Bouteloua curtipendula Vaughn.), Arizona fescue. black grama ( $B$. eriopoda Torr.), blue grama (B. gracilis H. B. K.), and bush muhly (Muhlenbergia porteri Scribn.). Germination of these warm season grasses did not decline to $50 \%$ or less until osmotic potentials were more negative than -1.5 MPa (Baskin and Baskin 1998a).

The steep decline in percent germination of big sacaton seeds at $-2.25 \mathrm{MPa}$ suggests that the critical osmotic potential is between -1.5 and $-2.25 \mathrm{MPa}$. This is contrary to a report by USDA Forest Service (1988) suggesting that big sacaton would not germinate well in low osmotic potentials. Our experiment, however, was conducted in a laboratory using an optimum temperature range, and the seeds were subjected to constant osmotic potentials within each treatment. Thus, our laboratory conditions may not have captured the variability in soil water present in natural

Table 2. Repeated measure analysis of variance of the effect of osmotic potential (OP) treatments and infection by Neotyphodium (endophyte) on percent and timing (day) of germination of

\begin{tabular}{ccrrrr}
\hline \hline Source & Sum of Squares & df & Mean Square & F-ratio & P \\
\hline Between Subjects & 128.4 & 5 & 25.7 & 18.3 & 0.000 \\
OP & 0.3 & 1 & 0.3 & 0.2 & 0.654 \\
Endophyte & 13.4 & 5 & 2.7 & 1.9 & 0.106 \\
OP x Endophyte & 84.2 & 60 & 1.4 & & \\
Error & & & & & \\
Within Subjects & 1199.6 & 6 & 199.9 & 57.2 & 0.000 \\
Day & 1938.6 & 30 & 64.6 & 18.5 & 0.000 \\
Day x OP & 18.9 & 6 & 3.1 & 0.9 & 0.494 \\
Day x Endophyte & 100.9 & 30 & 3.4 & 1.0 & 0.525 \\
Day x OP x Endophyte & 1257.4 & 360 & 3.5 & & \\
Error & &
\end{tabular}

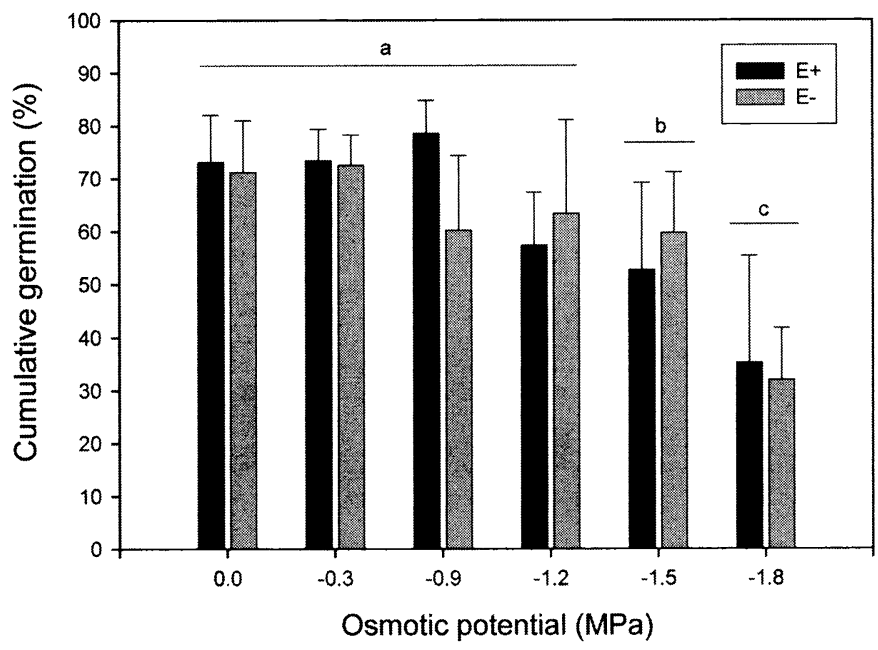

Fig. 4. Mean ( \pm SE) cumulative percent germination of Arizona fescue at different osmotic potentials. Different letters indicate significant differences $(P<0.05$, Tukey HSD test). Each bar represents the mean $( \pm \mathrm{SE})$ of 6 replicates of experimental units of 25 seeds. Dark bars are seeds infected with the Neotyphodium endophyte; gray bars are seeds with the Neotyphodium endophyte experimentally removed from the maternal plants. 

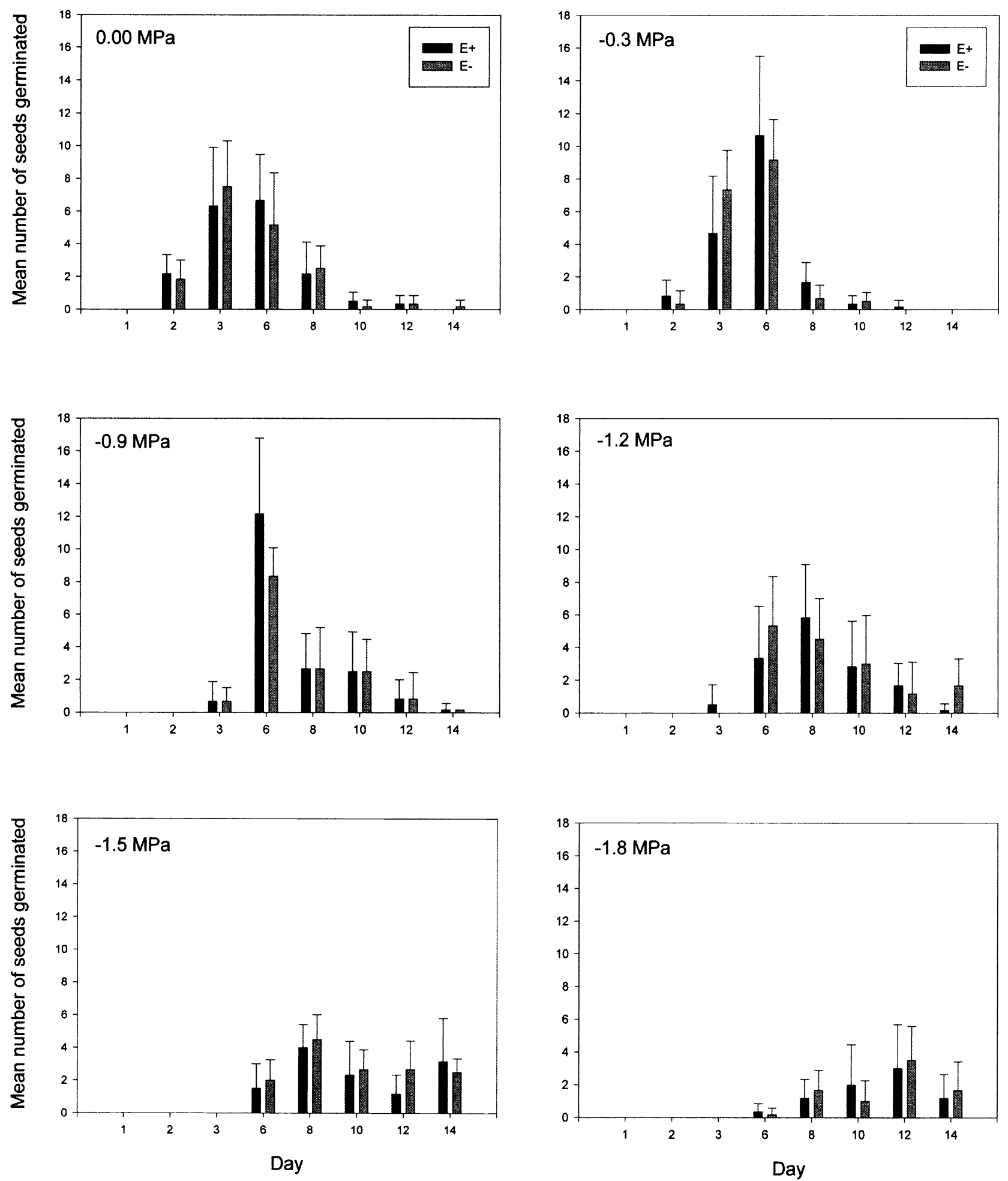

Fig. 5. Mean \pm time of Arizona fescue germination over a 14-day period at different osmotic potentials. Mean germination of E+ (infected) seeds did not differ from E- (uninfected) seeds at any osmotic potential or at any time period. Dark bars are seeds infected with the Neotyphodium endophyte; gray bars are seeds with the Neotyphodium endophyte experimentally removed from the maternal plants. 
settings. Further study is necessary to determine if high germination success compared to other semi-arid species and to past studies may have resulted from the artificial conditions of the laboratory, regional adaptation to southern Arizona, or some other factor.

The delay in peak germination at more negative osmotic potentials was expected. Delayed germination at more negative osmotic potentials has been observed for numerous other grasses and plants (McGinnies 1960, Qi and Redmann 1993 Brown 1995). The decreasing magnitude of peak germination paralleled declining germination with more negative osmotic potentials.

\section{Arizona Fescue}

Although Arizona fescue is a cool-season $\mathrm{C}_{3}$ grass that inhabits wetter and cooler areas than big sacaton (Kearney and Peebles 1960, Schulthess and Faeth 1998), total germination did not decline appreciably until $-1.5 \mathrm{MPa}$ (Fig. 4). Surprisingly, this is a more negative osmotic potential than that at which big sacaton first showed a significant decline $(-0.9 \mathrm{MPa})$. These results suggest that Arizona fescue germinates over a wide range of osmotic potentials, similar to, and perhaps even more flexible than, a warm-season $\mathrm{C}_{4}$ grass inhabiting drier regions. Generally, total germination was high compared to germination of other Festuca species. For example, Romo et al. (1991) reported germination of plains rough fescue (Festuca scabrella Torr.) of about $50 \%$ at $25^{\circ} \mathrm{C}$ and $-0.20 \mathrm{MPa}$. However, this could be an artifact of experimenting in the laboratory, dormancy, or other unknown factors.

Our prediction that infection by the Neotyphodium endophyte enhances germination success was not supported. Further, percent germination of $\mathrm{E}+$ and $\mathrm{E}$ - seeds did not differ across osmotic potentials. Our results thus do not support the hypothesis that the high frequency of endophyte infections in natural populations is explained by improved germination. For example, Clay (1987) found that seeds of infected agronomic perennial ryegrass and tall fescue germinated $10 \%$ more than uninfected seeds. Instead, our results corroborate those of Bacon (1993), where infection did not increase germination of tall fescue. Increased percent germination, however, is only one of several purported benefits of harboring asexual, systemic endophytes (e.g., Clay 1987, 1990). Arizona fescue does not show some of these other benefits such as increased herbivore resistance (Saikkonen et al. 1998,
Faeth and Sullivan 2003). However, infection may increase fitness of host related to other aspects of water availability. For example, infection may increase post-germination survival of seedlings at low soil water (Faeth and Bultman 2002, Faeth et al. 2002). Tests of how water availability affects seedling survival and adults await future experiments.

Like big sacaton, germination of Arizona fescue was delayed as osmotic potential became more negative (Fig. 5). However, delays began in Arizona fescue at less negative osmotic potentials than big sacaton and appear similar to the delays that McGinnies (1960) found in several species of Agropyron, another native, cool-season grass genus. These results suggest that although total germination of Arizona fescue remains relatively high through declining osmotic potentials, the timing of germination is sensitive to low osmotic potentials. Delays may be due to inhibitors present in the seeds. After physiological dormancy is broken, low osmotic potentials may result in delayed germination because of the longer time needed to leach out chemical inhibitors (Baskin and Baskin 1998b). Another possibility is that the seeds may need to absorb a specific amount of water to begin and continue the physiological processes involved in germination.

Big sacaton and Arizona fescue appear to germinate under a wide range of water stress. Future research should focus on seedling survival and establishment of these native grasses at varying osmotic potentials. Both grass species have been used in restoration projects on native grasslands in the southwestern United States and in revegetation attempts on disturbed areas (Pearson 1923, Nicholas and McGinnies 1982, Richter and Stutz 2001). Basic understanding of the requirements for germination and plant establishment of native species is vital for the success of these restoration projects. This is especially important in semi-arid regions where favorable conditions for germination and establishment may be rare (Briede and Mckell 1992, Brown 1995). In Arizona, for instance, conditions favorable enough for successful seeding may occur as infrequently as 1 in 10 years (Brown 1995). Understanding the parameters for germination of native seeds is a first step in determining the optimum time and conditions for restoration attempts.

\section{Literature Cited}

Adams, C. 1997. Germination strategies of native and exotic warm-season perennial grasses in response to variable moisture, light, and temperature. M. S. Thesis, Brigham Young Univ. Provo, Ut.

Bacon, C. 1993. Abiotic stress tolerances (moisture, nutrients) and photosynthesis in endophyte-infected tall fescue. Agr., Ecosystems, and Environ. 44:123-141.

Baskin, C. C. and J. M. Baskin. 1998a. Ecology of seed dormancy and germination in grasses, p. 30-83. In: G. Cheplick, (ed.) Population biology of grasses. Cambridge Univ. Press, Cambridge.

Baskin, C. C. and J. M. Baskin. 1998b. Seeds: ecology, biogeography, and evolution of dormancy and germination. Academic Press, San Diego, Calif.

Briedé, J.W. and C. M. McKell. 1992. Germination of seven perennial arid land species subjected to soil moisture stress. J. Arid Environ. 23:263-270.

Brown, R. W. 1995. The water relations of range plants: Adaptations to water deficits, $p$. 291-413. In: D. J. Bedunah and R. E. Sosebee (eds.) Wildland plants: physiological ecology and developmental morphology. Soc. Range Manage., Denver, Colo.

Clay, K. 1987. Effects of fungal endophytes on the seed and seedling biology of Lolium perenne and Festuca arundinacea. Oecologia. 73:358-362.

Clay, K. 1990. Fungal endophytes of grasses. Ann. Rev. Ecol. Syst. 21:275-297.

Elmi, A. A. and C. P. West. 1995. Endophyte infection effects on stomatal conductance, osmotic adjustment and drought recovery of tall fescue. New Phytol. 131:61-67.

Faeth, S. H. 2002. Are endophytic fungi defensive plant mutualists? Oikos. 98:25-36.

Faeth, S. H. and T. L. Bultman. 2002. Endophytic fungi and interactions among host plants, herbivores, and natural enemies, p 89-123. In: T. Tscharnkte and B. A. Hawkins (eds.) Multitrophic level interactions. Cambridge Univ. Press: Cambridge.

Faeth, S. H. and W. F. Fagan. 2002. Fungal endophytes: common host plant symbionts but uncommon mutualists. Integrated Comparative. Biol. 42:360-368.

Faeth, S. H. and T. J. Sullivan. 2003. Mutualistic, asexual endophytes in a native grass are usually parasitic. Amer. Nat. 161:310-325.

Faeth, S. H., S. M. Haase, S. S. Sackett, T. J. Sullivan, R. K. Remington and C. E. Hamilton. 2002. Does fire maintain symbiotic, fungal endophyte infections in native grasses? Symbiosis 32:211-228.

Hardegree, S. P. and W. E. Emmerich. 1992. Effect of matric-priming duration and priming water potential on germination of four grasses. J. Exper. Bot. 43:233-238.

Humphrey, R. R. 1970. Arizona range grasses: Their description, forage value and management. The Univ. Arizona Press, Tucson, Ariz. 
Kearney, T. H., R. H. Peebles, and collaborators. 1960. Arizona flora. Univ. of California Press, Berkeley, Calif.

Latch, G. C. M. 1993. Physiological interactions of endophytic fungi and their hosts: Biotic stress tolerance imparted to grasses by endophytes. Agr., Ecosystems., and Environ. 44:143-156.

McGinnies, W. J. 1960. Effects of moisture stress and temperature on germination of six range grasses. Agron. J. 52:159-162.

Michel, B. E. 1983. Evaluation of the water potentials of solutions of polyethylene glycol 8000 , both in the absence and presence of other solutes. Plant Physiol. 72:66-70
Nicholas, P. J. and W. J. McGinnies. 1982. An evaluation of 17 grasses and 2 legumes for revegetation of soil and spoil on a coal strip mine. J. Range Manage. 35:288-293.

Qi, M. Q. and R. E. Redmann. 1993. Seed germination and seedling survival of $\mathrm{C} 3$ and C4 grasses under water stress. J. Arid Environ. 24:277-285.

Pearson, G. A. 1923. Natural reproduction of western yellow pine in the southwest. USDA. Bull. 1105. USDA, U.S. Government Printing Office. Washington, D.C.

Richter, B. S. and J. C. Stutz. 2001. Mycorrhizal inoculation of big sacaton: implications for grassland restoration of abandoned agricultural fields. Restoration Ecol. (In press.)
Romo, J. T., P. L. Grilz, C. J. Bubar, and J. A. Young. 1991. Influences of temperature and water stress on germination of plains rough fescue. J. Range Manage. 44:75-81.

Saikkonen K., S. H. Faeth, M. Helander, and T. J. Sullivan 1998. Fungal endophytes:

A continuum of interactions with host plants. Annu. Rev. Ecol. Syst. 29:319-343.

Schulthess, F. M. and S. H. Faeth. 1998. Distribution, abundances, and associations of the endophytic fungal community of Arizona fescue (Festuca arizonica). Mycol. 90(4):569-578.

Sokal, R. R. and F. J. Rohlf. 1995. Biometry. $3^{\text {rd }}$ Edition. W. H. Freeman, New York, N.Y.

USDA, Forest Service. 1988. Range plant handbook. (Orig. 1937) Dover Pub., Inc., New York, N.Y. 